\title{
Ethephon and Gibberellic Acid Inhibitors Influence Creeping Bentgrass Putting Green Quality and Ball Roll Distances
}

\author{
Patrick E. McCullough ${ }^{1}$ \\ Department of Plant Biology and Pathology, Rutgers, The State University of \\ New Jersey, New Brunswick, NJ 08901-8520 \\ Haibo Liu ${ }^{2}$ and Lambert B. McCarty ${ }^{3}$ \\ Department of Horticulture, Clemson University, Clemson, SC 29634-0375
}

Additional index words. flurprimidol, paclobutrazol, stimpmeter, trinexapac-ethyl

Abstract. Plant growth regulators (PGRs) are often applied in combinations to reduce turf clippings, enhance turf quality, and suppress Poa annua L.; however, effects of PGR combinations on putting green ball roll distances have not been reported. Two field experiments were conducted on an 'L-93' creeping bentgrass (Agrostis stolonifera var. palustris Huds.) putting green in Clemson, S.C., to investigate effects of four PGRs with and without a subsequent application of ethephon at $3.8 \mathrm{~kg} \cdot \mathrm{ha}^{-1}$ a.i. 6 days after initial treatments. The PGRs initially applied included ethephon at $3.8 \mathrm{~kg} \cdot \mathrm{ha}^{-1}$ a.i., flurprimidol at $0.28 \mathrm{~kg} \cdot \mathrm{ha} \mathrm{a}^{-1}$ a.i., paclobutrazol at $0.28 \mathrm{~kg} \cdot \mathrm{ha}^{-1} \mathrm{a} . \mathrm{i}$., and trinexapac-ethyl at $0.05 \mathrm{~kg} \cdot \mathrm{ha}^{-1} \mathrm{a}$.i.. Ball roll distances were enhanced $3 \%$ to $6 \%(4$ to $8 \mathrm{~cm})$ by exclusive flurprimidol, paclobutrazol, and trinexapac-ethyl treatments. The additional ethephon application reduced ball distances $2 \%$ to $9 \%$ (2 to $11 \mathrm{~cm})$. Paclobutrazol and trinexapac-ethyl treated turf receiving the additional ethephon application had longer or similar ball roll distances to non-PGR treated turf. The additional ethephon treatment reduced turf quality to unacceptable levels 1 and 2 weeks after applications. However, bentgrass treated previously with trinexapac-ethyl and paclobutrazol had 8 to $16 \%$ higher visual quality following the additional ethephon treatment relative to non-PGR treated turf receiving the subsequent ethephon application. Overall, ethephon may have deleterious effects on monostand creeping bentgrass putting green quality and ball roll distances; however, applying ethephon with GA inhibitors could mitigate these adverse effects. Chemical names used: [4-(cyclopropyl-[ $\alpha]$-hydroxymethylene)-3,5-dioxo-cyclohexane carboxylic acid ethyl

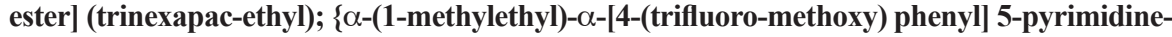
methanol\} (flurprimidol); (+/-)- $\left(\mathbf{R}^{*}, \mathbf{R}^{*}\right)-\beta-[(4-$ chlorophenyl) methyl]- $\alpha-(1,1$-dimethyl)-1H1,2,4,-triazole-1-ethanol (paclobutrazol); [(2-chloroethyl)phosphonic acid] (ethephon).

Creeping bentgrass putting greens require intensive management for successful long-term culture. Providing uniform surfaces for ball roll is an important economical aspect of bentgrass golf green management that may be hindered by uneven shoot growth and Poa annua (L.) infestations (Beard, 1973). Plant growth regulators (PGRs) are effective tools that help turf managers inhibit uneven leaf growth, suppress unsightly seedheads, and promote surface uniformity (Watschke et al., 1992).

Traditional PGRs used in turfgrass management inhibitcell division or gibberellic acid(GA) synthesis. For intensively managed turfgrasses, GA inhibitors are more frequently used than cell division inhibitors for less likelihood of leaf burn and turfgrass injury (Murphy et al., 2005). Incorporating GA inhibitors into golf course putting green management improves ball roll distances, enhances turf quality, and suppresses $P$. annua populations (Johnson and Murphy, 1995; Fagerness et al., 2000; Bell et al., 2004).

Received for publication 19 Oct. 2004. Accepted for publication $8 \mathrm{Jan} .2005$.

${ }^{1}$ Program associate. "To whom reprint requests should be addressed; e-mail haibol@clemson.edu.

${ }^{2}$ Associate professor.

${ }^{3}$ Professor.
Recently, PGR combinations have been implemented for P. annua seedhead suppression and to reduce bentgrass phytotoxicity from PGRs such as ethephon (Kane and Miller, 2003). Ethephon is an ethylene based PGR that effectively inhibits Poa annua seedheads in creeping bentgrass putting greens (Gelertner and Stowell, 2001). Ethylene diffusion suppresses Poa annua growth and causes seedhead abortion; however, discoloration may result from chlorophyll degradation of the desired bentgrass turf (Taiz and Zeiger, 2002). Combining ethephon with a GA inhibitor, trinexapac-ethyl, reduces discoloration and thinning of creeping bentgrass and has become a popular PGR combination for putting green management (Kane and Miller, 2003).

Despite increasing use of ethephon in combination with trinexapac-ethyl on golf course putting greens, the influence on ball roll distances have not been reported. Furthermore, the effects of ethephon applied with other GA inhibitors have not been reported. Information is also warranted concerning applications of ethephon for routine bentgrass putting green maintenance without significant $P$. annua infestations. The objectives of these field experiments were to investigate the use of three GA inhibitors with ethephon on creeping bentgrass putting green quality and ball roll distances.

\section{Materials and Methods}

Field experiments were conducted in 2004 at the Turfgrass Service Center, Clemson, S.C., on an experimental ' $\mathrm{L}-93$ ' creeping bentgrass putting green. The green was established in August 2002 and constructed approximately to U.S. Golf Association specifications (USGA Green Section Staff, 1993). Turf was maintained at a $3.2 \mathrm{~mm}$ mowing height and irrigated as needed to prevent plant wilt. Daily mowing was performed from 700 to $900 \mathrm{HR}$ with a reel-type greensmower(Toro, Bloomington, Minn.). The green was aerified 23 Sept. 2003 and 8 Mar. 2004 with $1.3 \mathrm{~cm}$ diameter hollow tines at 2.5 cm spacing. Beginning in March 2004, bentgrass was fertilized with $\mathrm{N}$ at $6 \mathrm{~kg} \cdot \mathrm{ha}^{-1} \cdot \mathrm{wk}^{-1}$, with a greens-grade granular fertilizer (Anderson's, Maumee, Ohio; 18N-1P-15K).

The experimental design was a split-block with three replications of $1.5 \times 1.8$-m plots. Five plots were arranged per block (four PGRs plus a control) in which PGRs were randomly assigned in each experiment. Plots were free of $P$. аппиа. The experiment was repeated on plots adjacent to those used for the first experiment. Flurprimidol, paclobutrazol, trinexapac-ethyl, and ethephon were initially applied as whole-plot treatments. Application dates and PGR rates are presented in Table 1. Turf treated with paclobutrazol and flurprimidolwere immediately irrigated to about $1 \mathrm{~cm}$ depth after treatments. Six days after initial PGR applications, ethephon was reapplied at $3.8 \mathrm{~kg} \cdot \mathrm{ha}^{-1}$ to half of each block. Applications were made with a $\mathrm{CO}_{2}$ sprayer calibrated to deliver $1800 \mathrm{~L} \cdot \mathrm{ha}^{-1}$.

Six ball roll measurements (three rolls in opposite directions) were made at about $1500 \mathrm{HR}$

Table 1. Treatment main effects from field experiments investigating the influence of plant growth regulators (PGRs) on 'L-93' creeping bentgrass putting green quality and ball roll distances.

\begin{tabular}{lc}
\hline Treatment & Rate $\left(\mathrm{kg} \cdot \mathrm{ha}^{-1}\right.$ a.i. $)$ \\
\hline PGR & --- \\
Untreated & 3.8 \\
Ethephon (2L) & 0.28 \\
Flurprimidol (50WP) & 0.28 \\
Paclobutrazol (2SC) & 0.05 \\
$\quad$ Trinexapac-ethyl (1EC) & \\
Application date & \\
$\quad$ Study 1: 15 May & \\
Study 2: 21 May & 0 \\
Ethephon application & \\
& 3.8 \\
\hline
\end{tabular}

${ }^{\mathrm{z}}$ Ethephon was applied $6 \mathrm{~d}$ after plant growth regulator applications.

Table 2. Experiment schedule from two field studies investigating effects of plant growth regulators on 'L-93' creeping bentgrass putting green ball roll distances.

\begin{tabular}{ll}
\hline Day of study & Schedule \\
\hline 1 & $\begin{array}{l}\text { Initial plant growth regulator } \\
\text { applications }\end{array}$ \\
6 & Additional ethephon applications \\
7 & First ball roll measurement \\
14 & Second ball roll measurement \\
21 & Third ball roll measurement \\
\hline
\end{tabular}


Table 3. Ball roll distances taken with a $38 \mathrm{~cm}$ stimpmeter for ' $\mathrm{L}-93$ ' creeping bentgrass treated with four plant growth regulators (PGRs) in two combined field experiments, Clemson, S.C.

\begin{tabular}{llccc}
\hline & & \multicolumn{3}{c}{$\begin{array}{c}\text { Ball roll (cm) } \\
\text { (day of study) }\end{array}$} \\
\cline { 3 - 5 } Ethephon $^{z}$ & PGR & 7 & 14 & 21 \\
\hline Untreated & Untreated & 125 & 135 & 131 \\
& Ethephon & 121 & 133 & 131 \\
& Flurprimidol & 129 & 135 & 136 \\
& Paclobutrazol & 133 & 142 & 141 \\
Treated & Trinexapac-ethyl & 131 & 137 & 138 \\
& Untreated & 118 & 133 & 129 \\
& Ethephon & 114 & 123 & 126 \\
& Flurprimidol & 122 & 133 & 128 \\
& Paclobutrazol & 127 & 137 & 131 \\
Source of variation & Trinexapac-ethyl & 129 & 136 & 132 \\
& LSD 0.05 & 3 & 7 & 8 \\
& Ethephon (EP) & & & $*$ \\
& PGR & $*$ & $*$ & $*$ \\
& EP $\times$ PGR & $*$ & $*$ & NS \\
\hline
\end{tabular}

${ }^{2}$ Ethephon was applied at 0 and $3.8 \mathrm{~kg} \cdot \mathrm{ha}^{-1}, 6 \mathrm{~d}$ after plant growth regulator applications.

NS,"Nonsignificant or significant at $P=0.05$ probability level.

Table 4. Turf quality for ' $\mathrm{L}-93$ ' creeping bentgrass treated with plant growth regulators (PGRs) in two combined field experiments, Clemson, S.C.

\begin{tabular}{|c|c|c|c|}
\hline \multirow[b]{2}{*}{ Ethephon $^{y}$} & \multirow[b]{2}{*}{ PGR } & \multicolumn{2}{|c|}{$\begin{array}{c}\text { Turf quality }{ }^{2} \\
\text { (1-9) } \\
\text { (day of study) }\end{array}$} \\
\hline & & 14 & 21 \\
\hline \multicolumn{4}{|l|}{ Untreated } \\
\hline & Untreated & 7.0 & 7.1 \\
\hline & Ethephon & 5.7 & 6.3 \\
\hline & Flurprimidol & 7.3 & 7.4 \\
\hline & Paclobutrazol & 7.3 & 7.3 \\
\hline & Trinexapac-ethyl & 7.7 & 7.6 \\
\hline \multicolumn{4}{|l|}{ Treated } \\
\hline & Untreated & 6.0 & 5.7 \\
\hline & Ethephon & 4.0 & 4.3 \\
\hline & Flurprimidol & 6.3 & 6.2 \\
\hline & Paclobutrazol & 6.7 & 6.6 \\
\hline & Trinexapac-ethyl & 6.5 & 6.3 \\
\hline $\mathrm{LSD}_{0.05}$ & & 0.4 & 0.6 \\
\hline \multicolumn{4}{|c|}{ Source of variation } \\
\hline Etheph & n (EP) & * & * \\
\hline PGR & & * & * \\
\hline $\mathrm{EP} \times \mathrm{P}$ & & * & NS \\
\hline
\end{tabular}

${ }^{2}$ Turf quality was rated on a 1 to 9 scale with $1=$ dead turf and $9=$ dark green turf. Ratings below 7 were considered unacceptable.

${ }^{y}$ Ethephon was applied at 0 and $3.8 \mathrm{~kg} \cdot \mathrm{ha}^{-1}, 6 \mathrm{~d}$ after plant growth regulator applications.

NS,"Nonsignificant or significant at $P=0.05$ probability level.

with a $38-\mathrm{cm}$ stimpmeter. The stimpmeter was raised from the ground until gravity caused ball roll off the cleft located on the opposite end. Ball roll distances were obtained with tape measures running parallel with the plots. The six rolls were pooled per treatment and subjected to an analysis of variance with SAS General Linear Model procedure (SAS Institute, Cary, N.C.). Ball roll measurements were made 1,7 , and $14 \mathrm{~d}$ after the additional ethephon application in both studies. The experiment schedule is presented in Table 2 and sampling dates are defined by day of study. Turfgrass visual quality was rated on a 1 to 9 scale with $1=$ dead turf and $9=$ ideal, dark green turf. Ratings below 7 were considered unacceptable. Mean separations were based on Fishers LSD test at the 0.05 probability level.

\section{Results}

Ball roll distances. Results were pooled over the two studies due to a lack of significant interactions with treatments (Table 3). Bentgrass treated with flurprimidol, paclobutrazol, and trinexapac-ethyl without the additional ethephon treatment had ball roll distances enhanced 3\% to $6 \%$ (4 to $8 \mathrm{~cm}) 1$ week after initial treatment (Day 7). Conversely, bentgrass treated initially with ethephon had ball roll distances reduced $3 \%(4 \mathrm{~cm})$ relative to non-PGR treated turf. The additional ethephon application, applied $6 \mathrm{~d}$ after initial PGR applications, reduced ball roll distances $5 \%(6 \mathrm{~cm}) 1 \mathrm{~d}$ after treatment over all PGR levels (Day 7).

Creeping bentgrass initially treated with ethephon, flurprimidol, and no PGR had ball roll distances reduced $2 \%$ to $9 \%(3$ to $11 \mathrm{~cm}$ ) one day after receiving the additional ethephon application (Day 7). Paclobutrazol and trinexapac-ethyl treated turf that received the additional ethephon application had longer or similar ball roll distances to non-PGR treated bentgrass throughout the experiment. Bentgrass treated exclusively with ethephon, flurprimidol, and trinexapac-ethyl had similar ball roll distances to non-PGR treated turf 2 and 3 weeks after initial treatment (Days 14 and 21). On these dates, bentgrass treated only with paclobutrazol had ball roll distances $5 \%$ to $8 \%$ (7 to $10 \mathrm{~cm}$ ) longer than non-PGR treated turf.

Turf quality. Study by treatment interactions were not detected for visual quality; therefore, the studies were combined. The additional ethephon treatment on Day 6 reduced turf quality to unacceptable levels on Days 14 and 21 across all PGR treatments (Table 4). However, bentgrass treated previously with trinexapacethyl and paclobutrazol had $8 \%$ to $16 \%$ higher visual quality following the ethephon treatment relative to non-PGR treated turf that received the additional ethephon application.

Comparing bentgrass not receiving additional ethephon applications, trinexapacethyl treated turf had visual quality enhanced $10 \% 2$ weeks after initial treatment (Day 14). Turf treated exclusively with paclobutrazol and flurprimidol had similar visual quality to untreated turf. Bentgrass treated initially with ethephon, without the subsequent application, had unacceptable visual quality.

\section{Discussion}

PGRs will continue to be a fundamental part of putting green culture to improve ball roll distances, enhance turf quality, and suppress $P$. annua growth. Although PGRs effectively suppress heavy $P$. annua populations and seedhead formation in bentgrass golf greens, selecting PGRs that do not exacerbate surface inconsistencies may be a critical issue when bentgrass is the predominant species. Ethephon appears to have deleterious effects on monostand bentgrass ball roll distances in less than $24 \mathrm{~h}$ after application. These adverse effects on putting green ball roll did not subside after two weeks which would be considered unacceptable, especially when short-term ball roll enhancements are desired for tournament play conditions.

Although applying ethephon with trinexapac-ethyl is a popular PGR regimen in putting green management, applications with all three GA inhibitors produced unacceptable bentgrass quality and did not enhance ball roll distances. Combining ethephon with GA inhibitors will likely not be applicable in bentgrass putting green management without significant $P$. аппиа infestations. Exclusive GA inhibitor applications appear to effectively enhance short-term ball roll distances on creeping bentgrass putting greens.

Lastly, this experiment was conducted on a monostand 'L-93' creeping bentgrass. Responses of cultivars, such as 'Crenshaw', 'Penncross', and other cultivars may vary following PGR treatments. The presence of Poa annua, routine fertilizations, and watering regimes may also influence creeping bentgrass putting green ball roll distances following PGR use and warrant further investigations.

\section{Literature Cited}

Bell, G., C. Stiegler, and K. Koh. 2004. Poa control: Perhaps there's hope. Golf Course Mgt. 72(3):123-126.

Beard, J.B. 1973. Turfgrass science and culture. Prentice-Hall, Englewood Cliffs, N.J.

Fagerness, M.J., F.H. Yelverton, J. Isgrigg, and R.J. Cooper. 2000. Plant growth regulators and mowing height affect ball roll and quality of creeping bentgrass putting greens. HortScience 35:755-759.

Gelertner, W. and L.J. Stowell. 2001. Advances in Poa seedhead management. Golf Course Mgt. 69(10):49-53.

Johnson, B.J. and T.R. Murphy. 1995. Effect of paclobutrazol and flurprimidol on suppression of Poа annua spp. reptans in creping bentgrass (Agrostis stolonifera) greens. Weed Technol. 9:182-186.

Kane, R. and L. Miller. 2003. Field testing plant growth regulators and wetting agents for annual bluegrass seedhead suppression. USGA Green Sect. Rec. 41(7):21-26.

Murphy, T.R., T. Whitwell, B. McCarty, and F.H. Yelverton. 2005. Turfgrass plant growth regulators, p. 705-714. In: L.B. McCarty (ed.). Best golf course management practices. 2nd ed. Prentice-Hall, Upper Saddle River, N.J.

SAS Institute. 1999. The SAS system for Windows. v. 8.2. SAS Inst., Cary, N.C.

Taiz L. and E. Zeiger. 2002. Plant physiology. 3rd ed. Sinauer Assoc., Sunderland, Mass.

United States Golf Association Green Section Staff. 1993. USGA recommendations for a method of putting green construction. The 1993 Revision. USGA Green Sect. Rec. 31(2):1-3.

Watschke, T.L. M.G. Prinster, and J.M. Brenninger. 1992. Plant growth regulators and turfgrass management, p. 557-588. In: D.V. Waddington, R.N. Carrow, and R.C. Shearman (eds.). Amer. Soc. Agron. Monogr. 32. Turfgrass. 